\title{
Local Anesthetics Transfer Across the Membrane: Reproducing Octanol-Water Partition Coefficients by Solvent Reaction Field Methods
}

\author{
Hana Kavcic, ${ }^{1,3}$ Nejc Umek, ${ }^{2}$ Domen Pregeljc, ${ }^{4}$ Neli Vintar ${ }^{1,3,5}$ and Janez Mavri ${ }^{5, *}$ \\ ${ }^{1}$ Clinical Department for Anesthesiology and Surgical Intensive Therapy of University Medical Center Ljubljana, \\ Slovenia \\ ${ }^{2}$ Institute of Anatomy, Faculty of Medicine, University of Ljubljana, Slovenia \\ ${ }^{3}$ Department of Anesthesiology and Reanimatology, Faculty of Medicine, University of Ljubljana, Slovenia \\ ${ }^{4}$ Department of Chemistry, Imperial College London \\ ${ }^{5}$ Laboratory of Computational Biochemistry and Drug Design, National Institute of Chemistry, \\ Ljubljana, Slovenia \\ *Corresponding author: E-mail: janez.mavri@ki.si
}

Received: 11-18-2020

Presented at the Annual Meeting of the Slovenian Chemical Society 2020

\begin{abstract}
Local anesthetics are one of the most widely used drug classes in clinical practice. Like many other biological molecules, their properties are altered depending on their protonation status, which is dependent on the $\mathrm{pH}$ of the environment. We studied the transport energetics of seven local anesthetics from the extracellular fluid across the biological membrane to the axoplasm in order to understand the effect of $\mathrm{pH}$ value on their efficacy and other pharmaco-dynamic properties. In this we applied three different methods of solvent reaction field in conjunction with quantum chemical calculations to reproduce experimental values of $n$-octanol/water partition coefficients for both neutral and protonated forms. Only the SMD method of Cramer and Truhlar was able to reproduce experimental partition coefficient values. The results are discussed in terms of the function of local anesthetics under physiological conditions and in the case of local acidosis.
\end{abstract}

Keywords: Local Anesthetics; solvent Reaction Field Methods; distribution Coefficient, protonation states

\section{Introduction}

Local anesthetics are a class of compounds originally developed from cocaine to expand its use as a numbing agent, while diminishing its unwanted side effects (e.g. disturbances in heart rhythm and heart attacks, neurological effects). They are currently the only drug class able to provide safe and effective local anesthesia and are widely used in medical and dental practice for pain control during surgical procedures and postoperative treatment. ${ }^{1,2}$ They work by inhibiting voltage-dependent sodium channels and therefore blocking the transduction of the action potential along the neuronal axon. ${ }^{3}$ While procedures done under local anesthesia are safer than general anesthesia, there remain possible complications, including the cardiotoxicity and neurotoxicity of certain local anesthetics. ${ }^{4}$ The success rate of the procedure is also substantially dependent on the skill level of the medical provider. ${ }^{5}$ Broadening the therapeutic window, reducing the toxicity and fine-tuning the pharmacodynamic properties of local anesthetics are a few of the key goals that can be achieved by furthering research into the physiochemical characteristics of local anesthetics.

Most local anesthetics are weak bases with an acid dissociation constant $\left(\mathrm{pK}_{\mathrm{a}}\right)$ of 7 to 10 , which means that at physiological $\mathrm{pH}$, both the protonated and neutral forms are present. ${ }^{6}$ In order to efficiently inhibit the channel, it is necessary for local anesthetics to first cross the biological membrane in their neutral form, diffuse to the receptor site and reprotonate before binding to the channel. ${ }^{7} \mathrm{Mem}$ brane partitioning of local anesthetics has been determined by several methods, e.g. spectrophotometrically determining the $n$-octanol/water partition coefficient ${ }^{6}$ or 
by thermodynamic optometric studies of the interaction of a dipalmitoylphosphatidylcholine (DMPC) bilayer membrane with local anaesthetics. ${ }^{8}$ Both found extensive partitioning of the neutral form of the local anaesthetic into the membrane. In recent years, computer modelling of local anaesthetic membrane transfer has been the method of choice, utilizing quantum chemistry calculations. Martin et al. examined the partitioning behaviour of the local anaesthetic benzocaine and found out that benzocaine favourably partitions into the lipid bilayer and is likely to accumulate just inside the lipid headgroups. ${ }^{9}$ This has been reproduced by similar experiments for lidocaine, tetracaine and articaine, embedded in the DMPC lipid bilayer, with similar results. ${ }^{10-12}$ These experiments confirm the idea that only the neutral form of local anaesthetics crosses the membrane in significant amounts. Membrane partitioning seems to be directly related to the potency $(6,8)$ and duration of action ${ }^{13,14}$ of local anaesthetics, however the mechanisms behind this observations are not clear. It should be emphasized that experimental techniques involving local anesthetic equilibrium properties and transport across the neuron membrane are extremely demanding and provide only a fraction of the necessary data. In this respect, $n$-octanol is a good approximation of a neuronal membrane and the $n$-octanol/water partition coefficient is an established property of a drug acting on the central nervous system needed to pass the hematoencephalic (blood-brain) barrier. ${ }^{15}$

The aim of this article is to calculate the n-octanol/ water partition coefficients for a few representative local anesthetics in their neutral and protonated forms and critically compare them with the experimental values. We calculated the free energy of transfer using the experimentally determined partition coefficients provided by Strichartz et al. ${ }^{6}$ We compared experimental values to the calculated values by using quantum chemical calculations and various solvent reaction field methods. The results are discussed in terms of their transport from the extracellular fluid to the axoplasm and in the opposite direction. The former determines onset of action and the latter defines the duration of action. The role of Schwann cells is also discussed.

\section{Experimental}

\section{1. Quantum Chemical Calculations}

We performed quantum chemical calculations of local anesthetics along with various solvent reaction field methods. The structures of all local anesthetics and their protonated analogs were built using the Molden v5.8 software package. ${ }^{16}$ Calculations were performed using the Gaussian 16 software package. ${ }^{17}$ The initial geometries of structures were optimized at the M06-2X/6-31+G(d,p) level, which is a good compromise between computational cost and reliability of results. For comparison, we performed the same calculations using the M06-2X/cc-PVDZ basis set for lidocaine. The effects of solvation were considered by applying various solvent reaction field methods including an integral equation formalism variant (IEFPCM) ${ }^{18}$ conductor-like polarizable continuum model $(\mathrm{CPCM})^{19}$ and universal solvation model, based on density (SMD) (20). Please note that the parameters of the SMD solvation models were obtained by fitting to reproduce solvation free energies for a large number of organic solutes in various solvents including $n$-octanol. ${ }^{20}$ In the present study two solvents were considered: water with a dielectric constant of 78.30 and $n$-octanol with a dielectric constant of 9.86. The latter is an established model for a biological membrane. ${ }^{21,22}$ In this respect, the solvation free energy of a substance in $n$-octanol versus the hydration free energy represents a standard measure of the ability of a drug to cross the membrane and is a standard procedure in the drug discovery process. All structures were optimized by including the solvent reaction field. ${ }^{23}$ By inclusion of the solvent reaction field, the Born-Oppenheimer surface obtains meaning of a free energy surface. For all minimized structures, a vibrational analysis was performed in the harmonic approximation. The calculated frequencies allowed for thermodynamic corrections of free energies at $298.15 \mathrm{~K}$.

\section{2. Distribution Coefficient of Local Anesthetics Between $\boldsymbol{n}$-Octanol and Water}

Because local anesthetics are weak bases with $\mathrm{pKa}$ values between 7 and 10, their protonation states are $\mathrm{pH}$ dependent. Since protonated species have much more favorable solvation energy in water than in $n$-octanol, it is anticipated that at acidic $\mathrm{pH}$ values, local anesthetics prefer to stay in the aqueous phase, while at neutral and basic $\mathrm{pH}$ values they show a higher tendency to stay in the $n$-octanol phase. Stricharz et al. ${ }^{6}$ performed measurements of local anesthetic partition between $n$-octanol and water buffer at extremely acidic $\mathrm{pH}$ and extremely basic $\mathrm{pH}$, providing partition coefficient data for protonated local anesthetics $\left[\mathrm{LA}^{+}\right]$and neutral local anesthetics $\left[\mathrm{LA}^{0}\right]$. For $\mathrm{pH}$ values between the two extreme cases, the distribution coefficients $\mathrm{Q}$ is $\mathrm{pH}$ and $\mathrm{pK}_{\mathrm{a}}$ dependent.

The distribution coefficient $[\mathrm{Q}]$ is an equilibrium constant and a measure of free energy. It is defined as the ratio of concentrations of local anesthetics in water and in $n$-octanol, both protonated $\left[\mathrm{LA}^{+}\right]$and neutral $\left[\mathrm{LA}^{0}\right]$ :

$$
Q=\frac{\left[L A^{0}\right]_{o}+\left[L A^{+}\right]_{o}}{\left[L A^{0}\right]_{w}+\left[L A^{+}\right]_{w}}
$$

where $\left[\mathrm{LA}^{0}\right]_{\mathrm{o}}$ stands for concentration of the neutral form of local anesthetic in $n$-octanol, $\left[\mathrm{LA}^{0}\right]_{\mathrm{W}}$ for its concentration in the aqueous solution, $\left[\mathrm{LA}^{+}\right]_{\mathrm{o}}$ the concentration of the protonated form of local anesthetic in $n$-octanol, and $\left[\mathrm{LA}^{+}\right]_{\mathrm{w}}$ the concentration in the aqueous solution.

If we expand the nominator and denominator on the right side of the equation by a factor of $1 /\left[\mathrm{LA}^{0}\right]_{\mathrm{w}}$, we obtain:

Kavcic et al.: Local Anesthetics Transfer Across the Membrane: ... 


$$
Q=\frac{\left[L A^{0}\right]_{o} /\left[L A^{0}\right]_{w}+\left[L A^{+}\right]_{o} /\left[L A^{0}\right]_{w}}{1+\left[L A^{+}\right]_{w} /\left[L A^{0}\right]_{w}}
$$

The partition coefficient of neutral species $\left[\mathrm{P}^{0}\right]$ is the ratio of neutral local anesthetic in $n$-octanol and water; $\left[\mathrm{LA}^{0}\right]_{\mathrm{o}} /\left[\mathrm{LA}^{0}\right]_{\mathrm{W}}$. Similarly, the partition coefficient of protonated species $\left[\mathrm{P}^{+}\right]$is the ratio of protonated local anesthetic in $n$-octanol and water; $\left[\mathrm{LA}^{+}\right]_{\mathrm{o}} /\left[\mathrm{LA}^{+}\right]_{\mathrm{w}}$. When we introduce these variables, we get the compact form of the equation:

$$
Q=\frac{P^{0}+P^{+}\left[L A^{+}\right]_{w} /\left[L A^{0}\right]_{W}}{1+\left[L A^{+}\right]_{w} /\left[L A^{0}\right]_{w}}
$$

By considering the relation $\ln (x)=\ln (10) \log (x)$ and introducing a new variable $\log \beta=p H-p K_{a}$, it is possible to write an equation for the local anesthetic distribution coefficient as a function of $\mathrm{pH}$ and $\mathrm{pK}_{\mathrm{a}}$.

$$
Q=\frac{P^{0}+P^{+} 10^{p K_{a}-p H}}{1+10^{p K_{a}-p H}}=\frac{P^{0}+\beta P^{+}}{1+\beta}
$$

Since the distribution coefficient is an equilibrium constant, we can calculate the corresponding difference in free energy of transfer from an aqueous solution with a certain $\mathrm{pH}$ value to the membrane, which is also the difference between the two energies of solvation. The equation reads:

$$
\begin{aligned}
& \Delta G=-k_{B} T \ln Q=-k_{B} T \ln \frac{P^{0}+P^{+} 10^{p K_{a}-p H}}{1+10^{p K_{a}-p H}}= \\
& =-k_{B} T \ln \frac{P^{0}+\beta P^{+}}{1+\beta}
\end{aligned}
$$

\section{Results}

Experimental $\mathrm{pK}_{\mathrm{a}}$ values, $n$-octanol/water partition coefficients and calculated free energy differences for the studied local anesthetics are collected in Table 1. Please note that all experimental values are from the article by Stricharz et al. ${ }^{6}$
Neutral local anesthetics generally prefer the membrane environment, whereas their protonated counterparts generally prefer water. Neutral etidocaine is 4900 times more likely to be in $n$-octanol than in water, while this number is only 304 for lidocaine. For protonated species, the situation is basically reversed as they prefer an aqueous environment. Protonated lidocaine is 16.7 times more likely to be in water than in $n$-octanol, while protonated etidocaine is 2.1 times more likely to be in water than in $n$-octanol. An exception is protonated bupivacaine, which still prefers the membrane environment. Ester linked local anesthetics share the same attributes with amide-linked ones. Neutral procaine and neutral 2-chloroprocaine are, respectively, 81 and 720 times more likely to be found in the membrane than in the aqueous environment. Protonated procaine is 500 times more likely to be in water than in $n$-octanol, while protonated 2-chloroprocaine is 38 times more likely to be in water than in $n$-octanol.

Calculated free energies for the transfer of neutral and protonated local anesthetics from water to $n$-octanol, calculated with three solvent reaction field methods (IEFPCM, CPCM and SMD) are collected in Table 2. Free energies for the transfer from water to $n$-octanol, calculated from the experimental results of Strichartz, are added for comparison.

The range of difference between experimental results and the results from the IEFPCM method is between 4.31 and $6.46 \mathrm{kcal} \mathrm{mol}^{-1}$ for the neutral form and between 2.05 and $5.19 \mathrm{kcal} \mathrm{mol}^{-1}$ for the protonated form. The range of difference for the CPCM method is between 3.16 and 6.61 $\mathrm{kcal} \mathrm{mol}^{-1}$ for the neutral form and between 1.05 and 4.71 $\mathrm{kcal} \mathrm{mol}^{-1}$ for protonated form. The range of difference for the SMD method is between 0.16 and $2.96 \mathrm{kcal} \mathrm{mol}^{-1}$ for the neutral form and between 0.03 and $5.15 \mathrm{kcal} \mathrm{mol}^{-1}$ for the protonated form.

The same comparison between the three solvation field methods was done in a different basis set (M06-2X/ cc-PVDZ) for lidocaine, with similar results. They are summarized in Table 3.

Table 1. Experimental $\mathrm{pK}_{\mathrm{a}}$ (acid dissociation constant) values, n-octanol/water partition coefficients and calculated free energy differences for

\begin{tabular}{|c|c|c|c|c|c|c|}
\hline Local anesthetic & Type & $\mathrm{pK}_{\mathrm{a}}{ }^{\exp }$ & $\mathbf{P}^{0}$ & $\mathbf{P}^{+}$ & $\begin{array}{c}\Delta \mathbf{G}_{\mathbf{w o}}{ }^{\mathbf{0}} \\
\left(\mathrm{kcal} \mathrm{mol}^{-1}\right)\end{array}$ & $\begin{array}{c}\Delta \mathbf{G}_{\mathbf{w o}}^{+} \\
\left(\mathrm{kcal} \mathrm{mol}^{-1}\right)\end{array}$ \\
\hline Procaine & ester & 9.06 & 81 & 0.002 & -2.60 & 3.68 \\
\hline 2-chloroprocaine & ester & 9.30 & 720 & 0.026 & -3.90 & 2.16 \\
\hline Lidocaine & amide & 8.19 & 304 & 0.06 & -3.38 & 1.66 \\
\hline Bupivacaine & amide & 8.21 & 2565 & 1.5 & -4.65 & -0.24 \\
\hline Etidocaine & amide & 8.11 & 4900 & 0.48 & -5.03 & 0.43 \\
\hline Mepivacaine & amide & 7.92 & 90 & 0.09 & -2.66 & 1.43 \\
\hline Ropivacaine & amide & 8.16 & 775 & 0.46 & -3.94 & 0.46 \\
\hline
\end{tabular}
studied local anesthetics. $\mathrm{pK}_{\mathrm{a}} \exp$ values refer to the experimentally calculated acid dissociation constants and were determined by the spectrophotometrical method. All experiments were performed at $25^{\circ} \mathrm{C}$. $\mathrm{P}^{0}$ is the n-octanol/water partition coefficient for the neutral form of local anesthetic, $\mathrm{P}^{+}$is the protonated form. $\Delta \mathrm{G}_{\mathrm{wo}}{ }^{0}$ refers to free energy for transfer of unprotonated local anesthetics from water to n-octanol, while $\Delta \mathrm{G}_{\mathrm{wo}}{ }^{+}$is the corresponding value for protonated species. 
Table 2. Calculated free energies for the transfer of neutral and protonated local anesthetics from water to n-octanol. Three solvent reaction field methods were used. $\Delta \mathrm{G}_{\mathrm{wo}}{ }^{0}$ and $\Delta \mathrm{G}_{\mathrm{wo}}{ }^{+}$refer to the calculated free energies for the transfer of neutral and protonated local anesthetics from water to $n$-octanol. Experimental free energy values for the transfer of local anesthetics in their neutral and protonated form from water to $\mathrm{n}$-octanol $\left(\Delta \mathrm{G}_{\mathrm{wo}}{ }^{0}(\exp )\right.$ and $\Delta \mathrm{G}_{\mathrm{wo}}{ }^{+}(\exp )$, respectively) are calculated from the experimental $\mathrm{n}$-octanol/water partition coefficients.(6) All values are given in $\mathrm{kcal} \mathrm{mol}^{-1}$.

\begin{tabular}{|c|c|c|c|c|c|c|c|c|}
\hline \multirow[b]{3}{*}{ Local Anesthetic } & \multicolumn{6}{|c|}{ Solvent Reaction Field Method } & \multirow[b]{3}{*}{$\Delta G_{w o}{ }^{0}(\exp )$} & \multirow[b]{3}{*}{$\Delta \mathrm{G}_{\mathrm{wo}}^{+}(\exp )$} \\
\hline & \multicolumn{2}{|c|}{$\begin{array}{c}\text { M06-2X/6-31+G(d,p) } \\
\text { IEFPCM }\end{array}$} & \multicolumn{2}{|c|}{$\begin{array}{c}\text { M06-2X/6-31+G(d,p) } \\
\text { CPCM }\end{array}$} & \multicolumn{2}{|c|}{$\begin{array}{c}\text { M06-2X/6-31+G(d,p) } \\
\text { SMD }\end{array}$} & & \\
\hline & $\Delta \mathrm{G}_{\text {wo }}{ }^{0}$ & $\Delta \mathrm{G}_{\text {wo }}{ }^{+}$ & $\Delta \mathrm{G}_{\text {wo }}{ }^{0}$ & $\Delta \mathrm{G}_{\text {wo }}{ }^{+}$ & $\Delta \mathrm{G}_{\text {wo }}{ }^{0}$ & $\Delta \mathbf{G}_{\text {wo }}{ }^{+}$ & & \\
\hline Procaine & 1.71 & 5.73 & 1.18 & 4.73 & -1.78 & 1.08 & -2.60 & 3.68 \\
\hline 2-chloroprocaine & 1.47 & 6.50 & 1.25 & 4.92 & -0.94 & -0.09 & -3.90 & 2.16 \\
\hline Lidocaine & 1.37 & 5.94 & 1.34 & 5.28 & -4.14 & 1.69 & -3.38 & 1.66 \\
\hline Bupivacaine & 1.81 & 4.95 & 1.96 & 4.47 & -3.68 & -2.05 & -4.65 & -0.24 \\
\hline Etidocaine & 1.21 & 5.62 & 0.79 & 4.93 & -5.19 & 1.38 & -5.03 & 0.43 \\
\hline Mepivacaine & 1.09 & 6.11 & 0.50 & 4.94 & -3.62 & -3.72 & -2.66 & 1.43 \\
\hline Ropivacaine & 2.18 & 5.32 & 1.21 & 4.95 & -3.61 & -1.36 & -3.94 & 0.46 \\
\hline
\end{tabular}

Table 3. Calculated free energies for the transfer of neutral and protonated lidocaine from water to n-octanol. $\Delta \mathrm{G}_{\mathrm{wo}}{ }^{0}$ and $\Delta \mathrm{G}_{\mathrm{wo}}{ }^{+}$refer to the calculated free energies for the transfer of neutral and protonated local anesthetics from water to n-octanol. Experimental free energy values for the transfer of local anesthetics in their neutral and protonated form from water to n-octanol $\left(\Delta \mathrm{G}_{\mathrm{wo}}{ }^{0}(\exp )\right.$ and $\Delta \mathrm{G}_{\mathrm{wo}}{ }^{+}(\exp )$, respectively) are calculated from experimental n-octanol water partition coefficients.

\begin{tabular}{|c|c|c|c|c|c|c|c|c|}
\hline & \multicolumn{6}{|c|}{ Solvent Reaction Field Method } & & \\
\hline & \multicolumn{2}{|c|}{$\begin{array}{c}\text { M06-2X/cc-PVDZ } \\
\text { IEFPCM }\end{array}$} & \multicolumn{2}{|c|}{$\begin{array}{c}\text { M06-2X/cc-PVDZ } \\
\text { CPCM }\end{array}$} & \multicolumn{2}{|c|}{$\begin{array}{c}\text { M06-2X/cc-PVDZ } \\
\text { SMD }\end{array}$} & & \\
\hline & $\Delta \mathrm{G}_{\mathrm{wo}}{ }^{0}$ & $\Delta \mathrm{G}_{\mathrm{wo}}^{+}$ & $\Delta \mathrm{G}_{\mathrm{wo}}{ }^{0}$ & $\Delta \mathrm{G}_{\mathrm{wo}}^{+}$ & $\Delta \mathrm{G}_{\mathrm{wo}}{ }^{0}$ & $\Delta \mathrm{G}_{\mathrm{wo}}{ }^{+}$ & $\Delta G_{w o}{ }^{0}(\exp )$ & $\Delta \mathrm{G}_{\mathrm{wo}}{ }^{+}(\exp )$ \\
\hline Lidocaine & 1.16 & 16.31 & 0.80 & 4.62 & -4.57 & 2.33 & -3.38 & 1.66 \\
\hline
\end{tabular}

The basis set cc-PVDZ, in conjunction with all applied solvation models, provided very similar results for lidocaine to those obtained with Pople's basis set $6-31+\mathrm{G}(\mathrm{d}, \mathrm{p})$.

\section{Discussion}

Our comparison of the free energies of solvation, calculated using three different solvation methods implemented in Gaussian 16, and free energies calculated from the experimental results of Strichartz et al., show that the best solvation model for predicting partition coefficients is the SMD method of Cramer and Truhlar.

Experimental data (Table 1) clearly demonstrate that all local anesthetics in their neutral form strongly prefer $n$-octanol over water. Therefore, at physiological conditions, the membrane does not represent a barrier to the transfer of local anesthetics from the extracellular liquid to the axoplasm since their population in the membrane is increased rather than decreased.

Local anesthetics are less effective when applied to inflamed tissue. ${ }^{24-26}$ Under inflammatory conditions, the $\mathrm{pH}$ of the extracellular fluid is lowered by 0.5 to $1 \mathrm{pH}$ unit giving rise to a shifted equilibrium for local anesthetics between the extracellular fluid and axoplasm. ${ }^{27}$ Concomitantly, intracellular $\mathrm{pH}$ does not change significantly, but stays at a $\mathrm{pH}$ value of around 7.1..$^{28,29}$ This results in the storage capacity of the membrane and Schwann cells constituting the myelin sheath and hydrophobic parts of other cells in the vicinity being significantly decreased. Preliminary calculations reveal that the storage capacity is decreased by a factor of about 3.5 relative to the physiological value. This is a plausible explanation for why local anesthetics are significantly less effective when applied to inflamed tissue. This conception is also supported by the clinical practice of co-administering sodium bicarbonate, which elevates the extracellular $\mathrm{pH}$ and allows for an increase in storage capacity of the surrounding tissue. ${ }^{30-32}$ The body reacts to inflammation by vasodilation, increasing blood flow through the affected area, thus removing more local anesthetic molecules from the target tissue, which could provide an additional explanation for the diminished efficacy and duration of action in inflamed tissues. $^{33}$

We performed the calculations with three solvent reaction field methods, namely IEFPCM, CPCM and SMD. The applied DFT method M06-2X was designed to reproduce thermochemical data including stabilities and barrier heights for chemical reactions. In conjunction with the flexible basis set $6-31+G(d, p)$, the applied quantum level of theory should faithfully reproduce the charge distribution as a necessary input for the solvation model. We also repeated the measurements for lidocaine for a different 
basis set (M06-2X/cc-PVDZ). The results differ only slightly from the results obtained with the Pople's basis set and are within the error margin of the method used, as shown in Table 3. All three methods correctly assume that the neutral form has a lower free energy of transfer from water to $n$-octanol compared to the protonated counterpart, as shown in Table 2. The IEFPCM method and CPCM method both predict that all the differences in free energy are positive, which conflicts with the experimental results. The SMD method aligns better with the experimental results but overstates the partitioning of protonated local anesthetics in $n$-octanol, e.g. the differences in free energy are negative in three cases, whereas, according to the experimental results, they are positive. The SMD method was validated by a critical comparison between the experimental and calculated values of partition coefficients for both neutral and protonated local anesthetics (vide infra).

Our results indicate that only the SMD solvation model reasonably reproduces experimental free energies of transfer from aqueous solution to $n$-octanol. For most local anesthetics, SMD deviates less than $2 \mathrm{kcal} \mathrm{mol}^{-1}$ from the experimental values. In contrast, both IEFPCM and CPCM failed significantly since they did not even qualitatively reproduce the experimental values i.e. preference for water versus $n$-octanol. It should be noted that the calculation of partition coefficients requires very accurate solvation models where two solvation free energies are subtracted from each other. Only the SMD model was properly parametrized for this demanding task since solvation parameters were adjusted to reproduce solvation free energy in several solvents including $n$-octanol. When determining the properties of other small organic compounds, the SMD model has proven to be the most precise solvation method as well. ${ }^{34-36}$ In this respect, we recommend application of the SMD solvation model during the process of designing novel local anesthetics. The COSMO-RS solvation model, which also proved to yield comparably reliable $n$-octanol/water partition coefficients, is unfortunately not implemented in Gaussian $16 .{ }^{35}$ It should be emphasized that among the applied solvent reaction field methods only SMD was parametrized to reproduce solvation free energy in $n$-octanol. The critical elements of parametrization are always nonbonding interactions with the solvent that include reversible work for cavity creation, a dispersion component of the solvation energy and an interaction between the charge distribution and dielectric continuum. PCM and CPCM did not reproduce the solvation energy in $n$-octanol and this is the main contribution to the discrepancy in the partition coefficient.

An alternative method for calculating the solvation free energy would be the treatment of several solvent molecules on the atomic level, inclusion of thermal averaging and application of one of the methods for free energy calculations, such as thermodynamic integration or perturbation. A critical component of such simulation are nonbonding solvent-solute interactions, especially atomic charges and the dispersion component of van der Waals parameters. We did not proceed in this direction since such calculations are much more demanding in terms of complexity and CPU time.

The ultimate approach for modeling local anesthetics distribution between various parts of the neuron such as the extracellular fluid, membrane, axoplasm and myelin sheath and voltage-gated sodium channel is molecular simulation with atomic resolution. Contributions by Lyubartsev and coworkers represent a valuable starting point in the this regard. ${ }^{10,11}$ It should be noted that Lyubartsev and coworkers ${ }^{10-12}$ did not explicitly calculate the partition coefficients but rather the potential of mean force for transferring local anesthetics from the aqueous phase to a membrane composed of dimyristoylphosphatidylcholine (DMPC). Therefore, it is not possible to calculate the $n$-octanol-water partition coefficient from the calculated potential of mean force and compare it with the experimental value. They did, however, demonstrate the relevance of the boundary separating the aqueous phase and the bilayer, which is the preferred position for local anesthetics. Van der Spoel et al. developed a calculation protocol for determining $n$-octanol/water partition coefficients for a series of potential toxins by using molecular dynamics simulation. ${ }^{35}$ It remains a challenge for the future to apply this approach to the studied local anesthetics. The structure of the voltage-gated sodium channel has been solved by cryo-electron microscopy with a resolution of $3.80 \AA$ A.(37) It remains a major challenge to model the binding of local anesthetics to the sodium channel binding site along with the associated conformational changes and decreased permeability to sodium ions. We are aware that correlation times for such conformational changes are long, which would require a very long simulation time.

In conclusion, our study represents a small step forward towards understanding the function of local anesthetics on a molecular level. We showed that the rate limiting step in the transport of local anesthetics from the point of bolus administration to the axoplasm is the macroscopic diffusion to and from the membrane, not the membrane crossing itself. Future challenges will include development of more sophisticated mathematical models of the process as well as clarification of the relevance of Schwann cells and other cells as lipid reservoirs and how they influence local anesthetic pharmacokinetics. The final goal is understanding the relationship between the structure of local anesthetics and their pharmacodynamic properties in order to design novel local anesthetics with the desired properties.

\section{Conclusions}

We demonstrated that local anesthetics flow from the compartment with a higher $\mathrm{pH}$ value to the compartment with a lower $\mathrm{pH}$ value since protonated local anesthetics have a more favorable solvation energy than their

Kavcic et al.: Local Anesthetics Transfer Across the Membrane: ... 
neutral counterparts. This is consistent with clinical experience, i.e. in tissue acidosis, local anesthetics are less effective. Experimental data show that all local anesthetics in their neutral form strongly prefer $n$-octanol over water, whereas the protonated form mostly prefers the aqueous environment. In quantum chemical calculations, only the SMD solvent reaction field method was able to predict the same behavior and it seems to be the best model for prediction of the $n$-octanol/water partition coefficient.

\section{Acknowledgments}

This work was supported by the Slovenian Research Agency (grant numbers P1-0012 and P3-0043). We would like to thank Tanja Gavranič of the National Institute of Chemistry, Ljubljana, Slovenia for her assistance with graphical work. We would also like to thank Ms. Charlotte Taft for proofreading the manuscript.

\section{References}

1. Miller R, Eriksson L, Fleisher L, Wiener-Kronish J, Cohen N, Young W. Miller's anesthesia: Chapter 36 Local Anesthetics. In: Miller's Anesthesia. 8th Editio. ELSEVIER Churchill Livingston, 2014.

2. Becker DE, Reed KL. Local Anesthetics: Review of Pharmacological Considerations. Anesth Prog. 2012, 59(2), pp. 90-102. DOI:10.2344/0003-3006-59.2.90

3. Kaplan MR, Meyer-Franke A, Lambert S, et al. Induction of sodium channel clustering by oligodendrocytes. Nature. 1997, 386(6626), pp. 724-728. DOI:10.1038/386724a0

4. Markova L, Umek N, Horvat S, et al. Neurotoxicity of bupivacaine and liposome bupivacaine after sciatic nerve block in healthy and streptozotocin-induced diabetic mice. BMC Vet Res. 2020, 16, pp. 247.

DOI:10.1186/s12917-020-02459-4

5. Helander EM, Kaye AJ, Eng MR, et al. Regional Nerve Blocks-Best Practice Strategies for Reduction in Complications and Comprehensive Review. Curr Pain Headache Rep. 2019, 23(6), pp. 43. DOI:10.1007/s11916-019-0782-0

6. Strichartz GR, Sanchez V, Arthur GR, Chafetz R, Martin D. Fundamental properties of local anesthetics. II. Measured octanol:buffer partition coefficients and $\mathrm{pKa}$ values of clinically used drugs. Anesth Analg. 1990, 71(2), pp. 158-170.

DOI:10.1213/00000539-199008000-00008

7. Wang G-K, Strichartz GR: State-dependent inhibition of sodium channels by local anesthetics: A 40-year evolution. Biochemistry (Mosc). 2012, 6, pp. 120-127.

DOI:10.1134/S1990747812010151

8. Hata T, Sakamoto T, Matsuki H, Kaneshina S. Partition coefficients of charged and uncharged local anesthetics into dipalmitoylphosphatidylcholine bilayer membrane: Estimation from $\mathrm{pH}$ dependence on the depression of phase transition temperatures. Colloids Surf B Biointerfaces. 2001, 22(1), pp. 77-84. DOI:10.1016/S0927-7765(01)00160-6
9. Martin LJ, Chao R, Corry B. Molecular dynamics simulation of the partitioning of benzocaine and phenytoin into a lipid bilayer. Biophys Chem. 2014, 185, pp. 98-107.

DOI:10.1016/j.bpc.2013.12.003

10. Saeedi M, Lyubartsev AP, Jalili S. Anesthetics mechanism on a DMPC lipid membrane model: Insights from molecular dynamics simulations. Biophys Chem. 2017, 226, pp. 1-13. DOI:10.1016/j.bpc.2017.03.006

11. Högberg CJ, Maliniak A, Lyubartsev AP. Dynamical and structural properties of charged and uncharged lidocaine in a lipid bilayer. Biophys Chem. 2007, 125(2-3), pp. 416-424. DOI:10.1016/j.bpc.2006.10.005

12. Jalili S, Saeedi M. Study of procaine and tetracaine in the lipid bilayer using molecular dynamics simulation. Eur Biophys J. 2017, 46(3), pp. 265-282.

DOI:10.1007/s00249-016-1164-8

13. Thut PD, Turner MD, Cordes CT, Wynn RL. A rabbit toothpulp assay to quantify efficacy and duration of antinociception by local anesthetics infiltrated into maxillary tissues. $J$ Pharmacol Toxicol Methods. 1995, 33(4), pp. 231-236. DOI:10.1016/1056-8719(95)00023-B

14. Langerman L, Golomb E, Grant GJ, Benita S. Duration of spinal anaesthesia is determined by the partition coefficient of local anaesthetic. Br J Anaesth. 1994, 72(4), pp. 456-459. DOI:10.1093/bja/72.4.456

15. Leo A, Hansch C, Elkins D. Partition coefficients and their uses. Chem Rev. 1971, 71(6), pp. 525-616.

DOI:10.1021/cr60274a001

16. Schaftenaar G, Noordik JH. Molden: a pre- and post-processing program for molecular and electronic structures. J Comput Aided Mol Des. 2000, 14(2), pp. 123-134. DOI:10.1023/A:1008193805436

17. Gaussian 16, Revision B.01, M. J. Frisch, G. W. Trucks, H. B. Schlegel, G. E. Scuseria, M. A. Robb, J. R. Cheeseman, G. Scalmani, V. Barone, G. A. Petersson, H. Nakatsuji, X. Li, M. Caricato, A. V. Marenich, J. Bloino, B. G. Janesko, R. Gomperts, B. Mennucci, H. P. Hratchian, J. V. Ortiz, A. F. Izmaylov, J. L. Sonnenberg, D. Williams-Young, F. Ding, F. Lipparini, F. Egidi, J. Goings, B. Peng, A. Petrone, T. Henderson, D. Ranasinghe, V. G. Zakrzewski, J. Gao, N. Rega, G. Zheng, W. Liang, M. Hada, M. Ehara, K. Toyota, R. Fukuda, J. Hasegawa, M. Ishida, T. Nakajima, Y. Honda, O. Kitao, H. Nakai, T. Vreven, K. Throssell, J. A. Montgomery, Jr., J. E. Peralta, F. Ogliaro, M. J. Bearpark, J. J. Heyd, E. N. Brothers, K. N. Kudin, V. N. Staroverov, T. A. Keith, R. Kobayashi, J. Normand, K. Raghavachari, A. P. Rendell, J. C. Burant, S. S. Iyengar, J. Tomasi, M. Cossi, J. M. Millam, M. Klene, C. Adamo, R. Cammi, J. W. Ochterski, R. L. Martin, K. Morokuma, O. Farkas, J. B. Foresman, and D. J. Fox, Gaussian, Inc., Wallingford CT, 2016.

18. Miertuš S, Scrocco E, Tomasi J. Electrostatic interaction of a solute with a continuum. A direct utilizaion of $\mathrm{AB}$ initio molecular potentials for the prevision of solvent effects. Chem Phys. 1981, 55(1), pp. 117-129. DOI:10.1016/0301-0104(81)85090-2

19. Cossi M, Rega N, Scalmani G, Barone V. Energies, structures, and electronic properties of molecules in solution with the 
C-PCM solvation model. J Comput Chem. 2003, 24(6), pp. 669-681. DOI:10.1002/jcc.10189

20. Marenich A V, Cramer CJ, Truhlar DG. Universal solvation model based on solute electron density and on a continuum model of the solvent defined by the bulk dielectric constant and atomic surface tensions. J Phys Chem B. 2009, 113(18), pp. 6378-6396. DOI:10.1021/jp810292n

21. Pignatello R, Musumeci T, Basile L, Carbone C, Puglisi G. Biomembrane models and drug-biomembrane interaction studies: Involvement in drug design and development. $J$ Pharm Bioallied Sci. 2011, 3(1), pp. 4-14.

DOI:10.4103/0975-7406.76461

22. Ritter J, Flower R, Henderson G, Rang H. Rang \& Dale's Pharmacology, 8th Edition. 8th Editio. Churchill Livingstone; 2015.

23. Schutz CN, Warshel A. What are the dielectric "constants" of proteins and how to validate electrostatic models? Proteins Struct Funct Genet. 2001, 44(4), pp. 400-417.

DOI:10.1002/prot.1106

24. Boronat López A, Peñarrocha Diago M. Failure of locoregional anesthesia in dental practice. Review of the literature. Med Oral Patol Oral Cir Bucal. 2006, 11(6), pp. E510-E513.

25. Potocnik I, Bajrović F. Failure of inferior alveolar nerve block in endodontics. Endod Dent Traumatol. 1999, 15(6), pp. 247251. DOI:10.1111/j.1600-9657.1999.tb00782.x

26. Ueno T, Tsuchiya H, Mizogami M, Takakura K. Local anesthetic failure associated with inflammation: verification of the acidosis mechanism and the hypothetic participation of inflammatory peroxynitrite. J Inflamm Res. 2008, 1, pp. 41-48. DOI:10.2147/JIR.S3982

27. Punnia-Moorthy A. Evaluation of $\mathrm{pH}$ changes in inflammation of the subcutaneous air pouch lining in the rat, induced by carrageenan, dextran and Staphylococcus aureus. J Oral Pathol. 1987, 16(1), pp. 36-44.

DOI:10.1111/j.1600-0714.1987.tb00674.x

28. Caldwell PC. Studies on the internal $\mathrm{pH}$ of large muscle and nerve fibres. J Physiol. 1958, 142(1), pp. 22-62.

DOI:10.1113/jphysiol.1958.sp005998
29. Madshus IH. Regulation of intracellular $\mathrm{pH}$ in eukaryotic cells. Biochem J. 1988, 250(1), pp. 1-8.

DOI:10.1042/bj2500001

30. Gupta S, Kumar A, Sharma AK, Purohit J, Narula JS. Sodium bicarbonate: an adjunct to painless palatal anesthesia. Oral Maxillofac Surg. 2018, 22(4), pp. 451-455.

DOI:10.1007/s10006-018-0730-x

31. Guo J, Yin K, Roges R, Enciso R. Efficacy of sodium bicarbonate buffered versus non-buffered lidocaine with epinephrine in inferior alveolar nerve block: A meta-analysis. J Dent Anesth pain Med. 2018, 18(3), pp. 129-142.

DOI:10.17245/jdapm.2018.18.3.129

32. Bailard NS, Ortiz J, Flores RA. Additives to local anesthetics for peripheral nerve blocks: Evidence, limitations, and recommendations. Am J Heal Pharm. 2014, 71(5), pp. 373-385. DOI:10.2146/ajhp130336

33. Huang AL, Vita JA. Effects of systemic inflammation on endothelium-dependent vasodilation. Trends Cardiovasc Med. 2006, 16(1), pp. 15-20.

DOI:10.1016/j.tcm.2005.10.002

34. Umek N. Cyclization step of noradrenaline and adrenaline autoxidation: a quantum chemical study. $R S C A d v$. 2020, 10 , pp. 16650-16658. DOI:10.1039/D0RA02713H

35. Van Der Spoel D, Manzetti S, Zhang H, Klamt A. Prediction of Partition Coefficients of Environmental Toxins Using Computational Chemistry Methods. ACS Omega. 2019, 4(9), pp. 13772-13781. DOI:10.1021/acsomega.9b01277

36. Bernales VS, Marenich A V., Contreras R, Cramer CJ, Truhlar DG. Quantum mechanical continuum solvation models for ionic liquids. J Phys Chem B. 2012, 116(30), pp. 9122-9129. DOI:10.1021/jp304365v

37. Shen H, Zhou Q, Pan X, Li Z, Wu J, Yan N. Structure of a eukaryotic voltage-gated sodium channel at near-atomic resolution. Science. 2017, 355, pp. 924.

DOI: $10.2210 / \mathrm{pdb} 5 \mathrm{x} 0 \mathrm{~m} / \mathrm{pdb}$

\section{Povzetek}

Lokalni anestetiki so eden najpogosteje uporabljenih razredov zdravil v klinični praksi. Tako kot pri mnogih drugih bioloških molekulah, se tudi njihove lastnosti spreminjajo glede na njihov protonacijski status, ki je odvisen od pH okolja. Proučevali smo transportno energetiko sedmih lokalnih anestetikov iz zunajcelične tekočine preko biološke membrane do aksoplazme, da bi razumeli vpliv vrednosti $\mathrm{pH}$ na njihovo učinkovitost in druge farmako-dinamične lastnosti. Pri tem smo uporabili tri različne metode reakcijskega polja topila v povezavi s kvantno-kemijskimi izračuni za reprodukcijo eksperimentalnih vrednosti koeficientov porazdelitve $n$-oktanol / voda za nevtralne in protonirane oblike. Samo SMD metoda Cramerja in Truhlarja je lahko reproducirala eksperimentalne vrednosti porazdelitvenih koeficientov. Rezultati so obravnavani v smislu funkcije lokalnih anestetikov v fizioloških pogojih in v primeru lokalne acidoze.

Except when otherwise noted, articles in this journal are published under the terms and conditions of the Creative Commons Attribution 4.0 International License

Kavcic et al.: Local Anesthetics Transfer Across the Membrane: ... 